\title{
Modern Molecular Genetic Technologies in the Supervision over HIV-1 Subtypes Girculation
}

DOI: $10.17691 / \mathrm{stm} 2016.8 .1 .16$

Received June 17, 2015

N.N. Zaitseva, MD, PhD, Head of the Department of Epidemiological Surveillance over HIV Infection,

Privolzhsky District AIDS Prevention and Control Center;

N.N. Nosov, MD, PhD, Head of Privolzhsky District AIDS Prevention and Control Center;

O.V. Parfenova, PhD, Biologist, Privolzhsky District AIDS Prevention and Control Center;

O.Y. Peksheva, Physician of Clinical Laboratory Diagnostics, Privolzhsky District AIDS Prevention and Control Center;

E.I. Efimov, MD, DSc, Professor, Director

Nizhny Novgorod Scientific and Research Institute of Epidemiology and Microbiology named after Academician I.N. Blokhina, Federal Service on Surveillance for Consumer Rights Protection and Human Welfare (Rospotrebnadzor), 71 Malay Yamskaya, Nizhny Novgorod, 603950, Russian Federation

The aim of the investigation was to assess the capabilities of modern technologies in the monitoring of genetic HIV-1 subtypes circulating within some administrative territories (by the example of Privolzhsky Federal District (PFD) during the period of 2008-2014).

Materials and Methods. We carried out molecular genetic analysis of 647 blood plasma samples of HIV-1 infected patients from 13 regions of PFD (Russia). Genotyping was carried out using a test kit ViroSeq ${ }^{\mathrm{TM}}$ HIV-1 and Genotyping System Software v.2.8 (Celera Diagnostic, USA). Subtyping was performed online using COMET HIV-1/2 and REGA HIV-1 Subtyping Tool, and Phylogenic analysis including reference nucleotide sequences from GenBank of European countries, America, Australia, CIS and Russian regions, was carried out using MEGA 5.2, Maximum Likelihood analysis and Kimura (bootstrap level 1000).

Results. The study of HIV-1 subtypes in PFD revealed the tendency for subtype A dominating, both in the period of 2008-2010 (91.3\%), and in 2011-2014 (95.6\%). Subtype B appeared to be the second most frequent HIV-1 subtype (8.7 and 2\%, respectively). We found the increase of subtype diversity of genetic HIV-1 variants in the samples dated 2011-2014, mainly, due to recombinant variants (AB, AG, CRF06_CPX, CRF01_AE) and subtype C strain.

There was revealed phylogenic affinity and proved molecular epidemiological relationships between nucleotide sequences of viruses isolated in HIV positive patients in PFD, and the sequences taken as reference from international base GenBank.

Conclusion. Modern molecular genetic techniques used in epidemiological surveillance over HIV infection, and when studying subtype structure of HIV, can serve as the prime tools to monitor a current situation, as well as for epidemic prognosis. The methods are able to assess, study the subtypes in order to make decisions for developing preventive and anti-epidemic measures to stabilize HIV infection epidemic.

Key words: HIV infection; molecular genetic technologies; HIV-1 subtypes; molecular epidemiological monitoring; recombinant HIV forms; phylogenic analysis.

The implementation of a complex of modern molecular genetic technologies characterized by high sensitivity and specificity extends the boundaries of epidemiological diagnostics of infections including human immunodeficiency virus (HIV) in terms of studying biological and genetic characteristics of an infectious agent. These technologies enable to study subtypical HIV variety that is one of biological parameters when supervising HIV infection [1].

The study of HIV-1 subtypes circulating in Russia has been carried out by different researchers. It enabled to reveal that in the middle 90 s of the last century A-H subtypes of HIV-1 circulated in Russia, subtype $B$ dominating among men having sex with men, and subtype $\mathrm{G}$ isolated in infected children from a nosocomial center of infection in the south of Russia. The other episode of HIV infection broke out in the middle of 1996 among people taking intravenous psychotropic agents, the infection being caused by subtype $A$ virus, which subsequently went beyond this vulnerable population group and started spreading among the sexual partners of injection drug users (IDU), as well as among children with perinatal HIV contact, and took the first rank in the Russian Federation [2-8]. In the following years in Russia recombinant forms obtained a wide circulation; the forms resulted from genetic material exchange of different virus subtypes circulating both in Russia, and on the territories of other countries and brought in Russia [9, 10].

Privolzhsky Federal District (PFD) is of special interest concerning the study of HIV subtypes incidence due to a high prevalence level and high morbidity rate of HIV infection, since 2000 it has exceeded a mean value in Russia. PFD is one of highly developed areas in Russia, has a unique transit position, since it is located at the junction of international transport corridors: "NorthSouth" and "West-East" connecting Siberia and Far

For contacts: Natalia N. Zaitseva, e-mail: vtashca@mail.ru 
East, as well as Eastern Asia and European countries. The last mentioned is curtain to contribute to a spectrum of HIV subtypes circulating in PFD.

The use of modern laboratory techniques is of scientific and practical importance, and the techniques enable to obtain the relevant information on genetic variation and HIV incidence in PFD as the supplement to classical epidemiological methods of epidemic monitoring.

The aim of the investigation was to assess the capabilities of modern technologies in the monitoring of genetic HIV-1 subtypes circulating within some administrative territories (by the example of Privolzhsky Federal District during the period of 2008-2014).

Materials and Methods. We carried out molecular genetic analysis of 647 blood plasma samples of HIV-1 infected patients from 13 regions of PFD, the patients being registered at local prevention and control centers for AIDS and infectious diseases. Nucleotide sequences of HIV-1 genome were identified using ViroSeq ${ }^{\text {TM }}$ HIV-1 Genotyping System (Celera Diagnostic, Abbott Laboratories, USA) by sequencing amplified fragments of gene pol on a genetic analyzer ABI Prism 3100 (Applied Biosystems, USA). The obtained fragments were studied using ViroSeq HIV-1 Genotyping System Software v.2.8 (Celera Diagnostic, USA) according to the manufacturer instructions. To identify closely related HIV-1 strains, nucleotide sequences including reference nucleotide sequences from GenBank of European countries, America, Australia, CIS and Russian regions were analyzed using BLAST program [http://www.ncbi. $\mathrm{nlm}$.iv.gov/BLAST/]. Phylogenic analysis was carried out using MEGA 5.2, Maximum Likelihood statistical analysis and Kimura (bootstrap level 1,000).

Subtyping of HIV-1 strains was performed using online programs COMET HIV-1/2 and HCV and REGA HIV-1 Subtyping Tool.

The obtained in the research nucleotide sequences of virus (HIV) isolate genome areas were subsequently deposited in an international database GenBank (JX 141197-JX 141233; KF257850-KF257884; KJ722070-
KJ722139; KP090065-KP090099) and Russian HIV drug resistance database.

The findings were processes using an analysis of variance. The difference degree of two samplings was assessed by Student t-test. The revealed differences were considered significant if $p<0.05$.

Results and Discussion. The implementation of modern computer programs and technologies in this research enabled to find the distribution of HIV-1 subtypes in PFD in different periods to have some differences. So, the samples dated 2008-2010 (the first period) appeared to be genotyped as variant $A$ in $91.3 \pm 1.7 \%$ cases; and as variant $B$ in $8.7 \pm 1.6 \%$ (Figure $1(\mathrm{a})$ ). No other virus types were identified during that period.

Subtype A occurs primarily $(90.7 \pm 1.7 \%$ cases $)$ in a group of those taking psychoactive substances parenterally, and live in the regions of Nizhny Novgorod, Samara, Kirov, Penza, Ulyanovsk, Saratov, and Republics of Udmurtia, Chuvashia, Mari El, Mordovia. Type $B$ was found only among men having sex with men living in Nizhny Novgorod and Penza regions.

During the second period (2011-2014) the spectrum of HIV-1 subtypes significantly extended, mainly, due to various recombinant types and subtype $C$ strain appeared (Figure 1 (b)).

The appearance of both new HIV-1 subtypes, as well as their recombinant forms in some regions reflects certain regularities in epidemiological process development. It is related to the virus evolution peculiarities, new population groups with various routes involved in an epidemiological process [11], the extension of economic and political relations between countries and the development of active migration and international tourism [5]. However, new HIV subtypes appeared to have an effect on the epidemic development in general that requires further study of their role.

HIV-1 subtypes isolated in the samples from the district areas in 2011-2014 have the following variants (See the Table).

The results of the studies carried out using modern

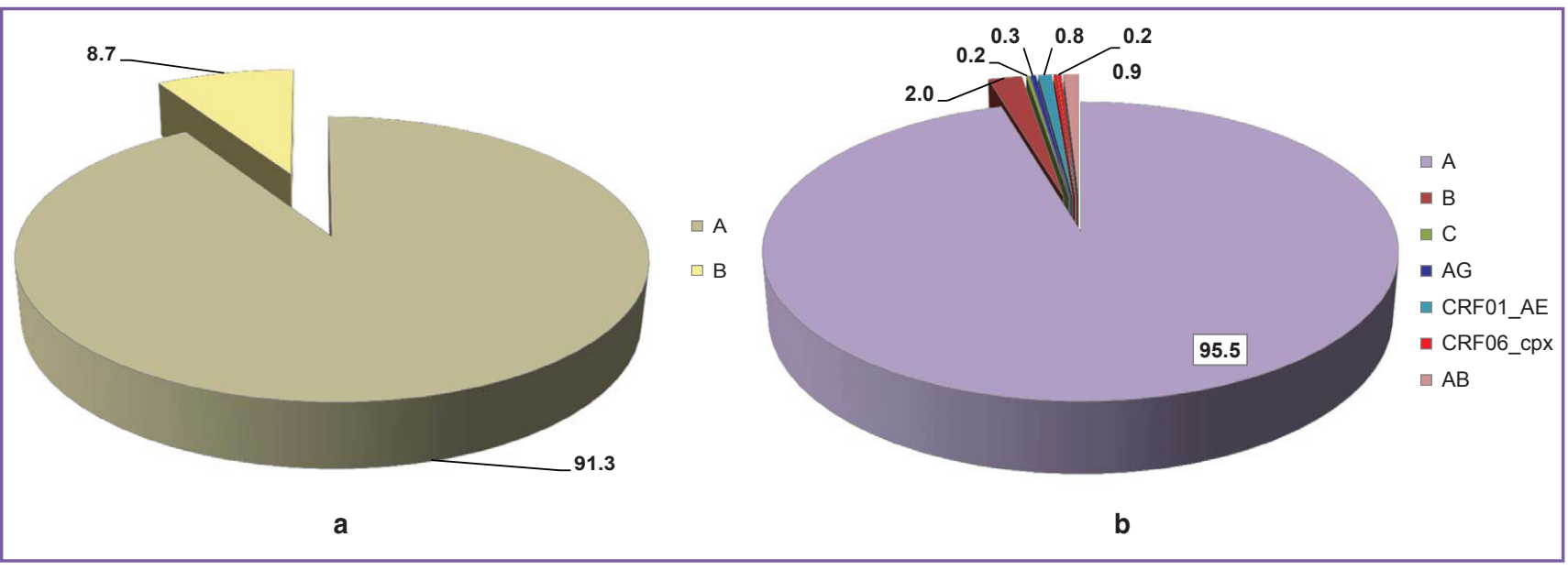

Figure 1. Distribution of HIV-1 subtypes (\%) in Privolzhsky Federal District in the period of 2008-2010 (a) and 2011-2014 (b) 
Territorial distribution of HIV-1 subtypes in Privolzhsky Federal District in 2011-2014

\begin{tabular}{|c|c|c|}
\hline $\begin{array}{c}\text { HIV-1 } \\
\text { subtypes }\end{array}$ & $\begin{array}{c}\text { Detection rate } \\
(\%)\end{array}$ & Privolzhsky Federal District territories with HIV-1 subtype revealed \\
\hline A & 95.6 & $\begin{array}{l}\text { Nizhny Novgorod, Ulyanovsk, Samara, Penza, Kirov, Orenburg, Saratov } \\
\text { regions, Republics of Chuvashia, Udmurtia, Mordovia, Mari El, Tatarstan, } \\
\text { Bashkortostan }\end{array}$ \\
\hline B & 2.0 & Nizhny Novgorod, Penza, Kirov regions, Republics of Chuvashia, Udmurtia \\
\hline C & 0.2 & Samara region \\
\hline$A G$ & 0.3 & Samara region \\
\hline$A B$ & 0.9 & Nizhny Novgorod, Ulyanovsk, Kirov, Saratov regions \\
\hline CRF06_cpx & 0.2 & Kirov region \\
\hline CRF01_AE & 0.8 & Nizhny Novgorod, Samara regions, Republic of Chuvashia \\
\hline
\end{tabular}

molecular genetic techniques enabled to establish that in the period of 2011-2014 A subtype continued to have a leadership position and was revealed in $95.6 \pm 0.9 \%$ cases on all the territories of the district, the most frequently detected in positive patients living in Nizhny Novgorod, Ulyanovsk, Samara regions and the Republic of Udmurtia $(p \leqslant 0.05)$.

The development of HIV epidemiological process through time and sequential involvement of general population in epidemic reflected the more frequent subtype A detection than during the first period in patients infected through sexual (heterosexual) transmission: $20.3 \pm 1.7 \%(p \leqslant 0.05)$ and, subsequently, the variant was detected in children with perinatal HIV contact during the second period: $2.4 \pm 0.6 \%$. This viral variant compared to the period of 2008-2010 was found in a group of HIV positive patients in fewer cases: $77.3 \pm 1.8 \%(p \leqslant 0.05)$ holding the dominant position.

The implementation of modern technologies, which enable to establish genetic relationship between nucleotide sequences of test and reference samples (phylogenic analysis) testify that most subtypes $A$ isolated from HIV positive patients from PFD were clustered around Ukrainian and Russian consensus samples both during the first and the second periods (Figure 2).

Variant $B$ ranked second in the terms of detection rate in 2011-2014 (2.0 $\pm 0.6 \%)$, it circulating on five territories of the district (Nizhny Novgorod, Penza, Kirov regions, Republics of Udmurtia and Chuvashia). During this period subtype $\mathrm{B}$ also dominated among men having sex with men $(53.8 \pm 2.2 \%)$, however, in $38.4 \%$ cases it was isolated in heterosexual men and women, who had had in their past history promiscuous sexual relations with citizens of Europe, Asia, America and both within and beyond Russia. Thus, viral distribution went beyond a group of homo- and bisexuals (See Figure 2). During both periods the obtained nucleotide sequences of $B$ variants were clustered with subtype $B$ sequences taken as references from GenBank, from European countries, America, Australia, CIS, and other Russian regions.

Among the samples under study, HIV-1 subtype C in PFD was found once, in HIV positive patient from
Samara region, who had been working in Ethiopia and had been infected there by sexual contact. It was proved by phylogenic analysis (See Figure 2): the sample obtained from this patient forms a common branch with the variants of the same subtype from Senegal (West Africa) and Burundi (East Africa).

Recombinant form $A B$ was first found in Russia in IDU of Kaliningrad region [12, 13] and for a relatively long period it was found only there. Later, the carryings of the virus were found in other region of Russia as well that was proved by phylogenic analysis and represented in our study. This variant was detected on four territories of PFD (Nizhny Novgorod, Kirov, Saratov, Ulyanovsk regions) with predominating frequency (66.7\%) among women infected by their husbands with a great number of sexual contacts (rotation workers, long distance truckers), and drug abusers from penitentiaries. Nucleotide sequences of the strains under study of type $A B$ virus form a common branch with recombinants from Kaliningrad region (Russia) and Belarus (See Figure 2).

$A G$ variant, which is widespread in Central Asian countries, was revealed in two HIV positive female patients from Samara region. Both patients were infected through sexual contacts with little-known partners from other regions of Russia. Nucleotide sequences of $A G$ variants under consideration quite expectably form a common branch with strains from Uzbekistan and Russian strain from Krasnodar.

HIV-1 CRF01_AE nucleotide sequences isolated in patients from Nizhny Novgorod region and Republic of Chuvashia form a common cluster with recombinant strains from European countries (Slovenia, Spain), Central Asia countries (Republics of Kazakhstan, Uzbekistan) and Russian strains (Irkutsk, Smolensk). In $2 / 3$ cases this recombinant was revealed in HIV positive drug abusers.

Circulating recombinant form CRF06_cpx was found in one woman from Kirov region. She had been infected through sexual contacts with an HIV positive partner from Saint Petersburg, who had had promiscuous sexual relations in his past history. It agrees with data reported in literature [14], which state that since 2000 in Saint Petersburg variant CRF06_cpx has been registered 


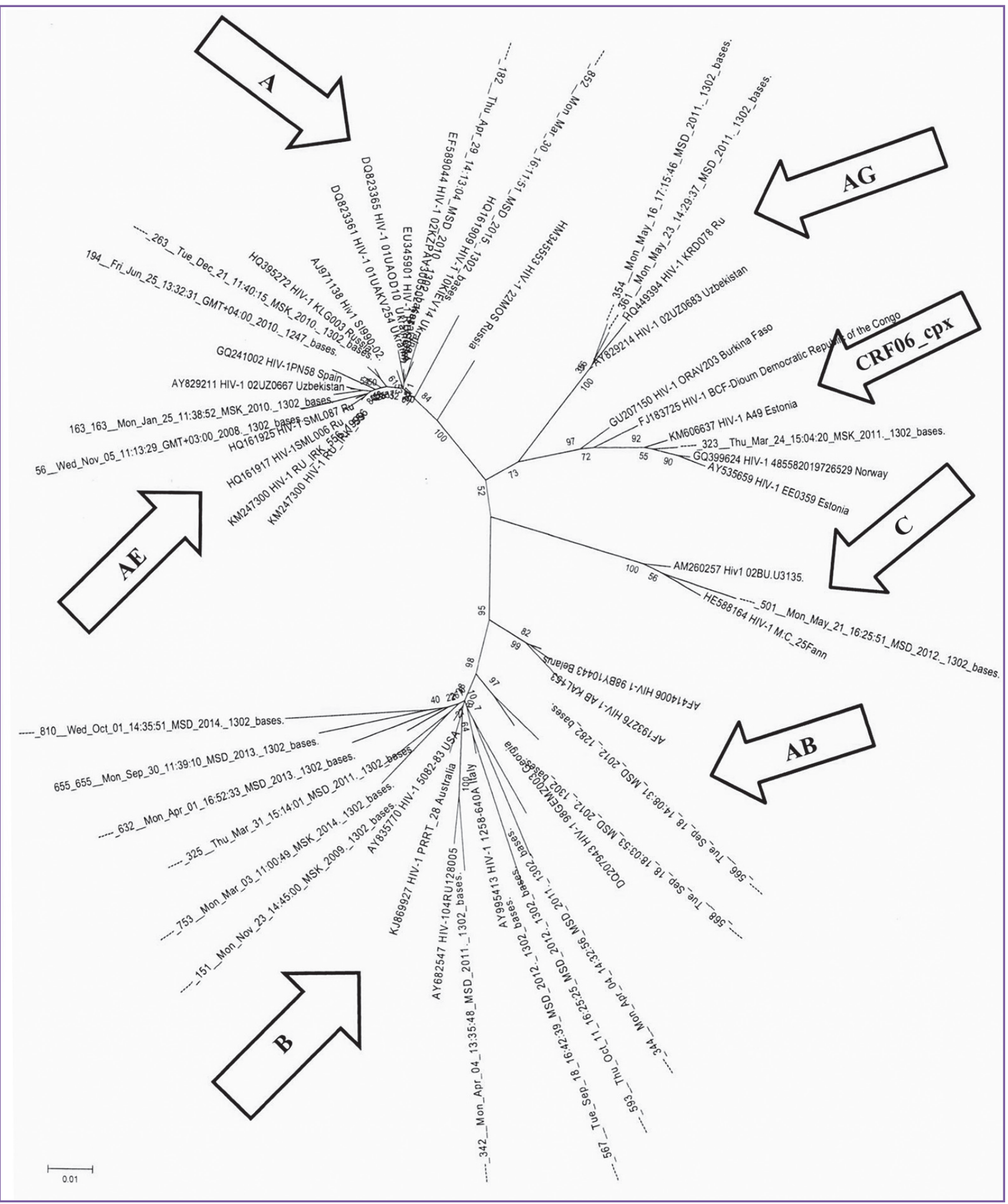

Figure 2. Spectrum of HIV-1 subtypes circulating in constituent units of Privolzhsky Federal District. A phylogenetic tree built based on the analysis of gene pol genome fragments of Russian and foreign HIV-1 strains

relatively frequently. This fact is clearly explained by geographical neighborhood with Estonia, where this HIV-1 recombinant is dominating among IDU [15], this subtype being widespread in West African countries in the 80-90s of the last century [16]. The phylogenic analysis carried out confirmed genetic proximity of the 
sample under study (See Figure 2) with the strains from Estonia, Norway and Central and West African countries (Democratic Republic of the Congo and Burkina Faso) forming a common cluster.

Thus, modern molecular genetic techniques enabled to establish that the distribution of HIV-1 subtypes in PFD complies with common regularities related to both genetic HIV variation, and, to a greater degree, with economic and epidemiological peculiarities of HIV-1 infection pandemic.

It should be noted that going further, due to the extension of migration flows, the spectrum of HIV subtypes in the district is likely to extend. So, in 2014, according to census report form No.4 "Information on the findings of HIV blood test", there were tested 30,550 people arrived at PFD from Ukraine for humanitarian reasons. It resulted in 2.5 increase of HIV positive patients detected: up to $0.3 \%$ among all foreigners, up to $0.6 \%$ among Ukrainians. The circumstances specified are likely to make a certain contribution to the development of HIV infection epidemiological process in the district in terms of a great variety of subtypical viral structure, the spectrum of revealed mutations of HIV resistance to antiretroviral agents, etc. The implementation of modern molecular technologies to study genetically the peculiarities of human immunodeficiency virus can serve an important tool to monitor a current situation and prognosticate an epidemic. These methods will make it possible to assess, study and make decisions in order to develop preventive and epidemiological measures to high precision and efficiently, since these techniques are an diagnostic component of epidemiological surveillance over HIV infection.

Acknowledgements. The authors express their thanks to the staff members of territorial and republican AIDS prevention and infectious diseases and control centers from Kirov, Nizhny Novgorod, Penza, Samara, Ulyanovsk regions, Republics of Udmurtia and Chuvashia for data and materials provided.

Study Funding and Conflicts of Interest. The study was not funded by any sources, and the authors have no conflicts of interest related to the present study.

\section{Литература/References}

1. Analiz epidemiologicheskoy situatsii po VICh-infektsii $i$ soputstvuyushchim zabolevaniyam (tuberkulez, IPPP, gepatity): metodicheskie rekomendatsii No.6964-RKh [The analysis of epidemiological situation in HIV infection and comorbidities (tuberculosis, STD, hepatites): guidelines No.6964-PX]. Moscow; 2007.

2. Bogachev V.V., Totmenin A.V., Baryshev P.B., Mescheryakova Yu.V., Chernousova N.Ya., Gashnikova N.M. Molecular-genetic characteristic of HIV-1 A and B subtypes variants isolated in Novosibirsk region. Zh Mikrobiol Epidemiol Immunobiol 2012; 6: 45-52.

3. Bogoslovskaya E.V. Kompleks molekulyarnogeneticheskikh metodov dlya monitoringa VICh-infektsii. Avtoref. dis. ... dokt. med. nauk [A complex of molecular genetic methods for HIV infection monitoring. DSc Thesis]. Saint Petersburg; 2011.
4. Bogoslovskaya E.V., Voloshina P.V., Braslavskaya S.I., Myznikova A.I., Shipulin G.A. Izuchenie rasprostranennosti razlichnykh subtipov VICh na territorii RF. V kn.: Materialy VII Vserossiyskoy nauchno-prakticheskoy konferentsii "Molekulyarnaya diagnostika" [The prevalence rate study of different HIV subtypes in the Russian Federation. In: Proceedings of the VII All-Russian research and practice conference "Molecular diagnostics"]. Moscow; 2010; p. 16-19.

5. Kazennova E.V., Bobkov A.F. Subtypes of human immunodeficiency virus 1: classification, the origin and circulation in Europe. Zh Mikrobiol Epidemiol Immunobiol 2003; 1: 90-96.

6. Lopatukhin A.E., Kireev D.E., Shipulin G.A. Izuchenie rasprostranennosti variantov VICh razlichnykh subtipov na territorii Rossiyskoy Federatsii $s$ ispol'zovaniem bazy dannykh lekarstvennoy ustoychivosti VICh. V kn.: Materialy mezhdunarodnoy konferentsii "Obshchie ugrozy - sovmestnye deystviya. Otvet gosudarstv BRIKS na vyzovy opasnykh infektsionnykh bolezney" [The study of prevalence rate of different HIV subtypes on the Russian Federation territory using database of HIV drug resistance. In: Proceeding of the International conference "Shared threats - collaborative actions". BRICS response to the challenge of dangerous infectious diseases"]. Moscow; 2015; p. 241-243.

7. Musatov V.B., Yakovlev A.A., Tirgina T.V., Ladnaya N.N. The prognostic significance of the results of genotyping human immunodeficiency virus isolated from the patients with primary HIV-infection in 2009 and 2011 in St. Petersburg. Vestnik SanktPeterburgskogo universiteta. Seriya 11: Meditsina 2013; 1 : 171-178.

8. Sukhanova A.L., Kazennova E.V., Bobkova M.R., Kravchenko A.V., Selimova L.M., Khanina T.A., Bobkov A.F., Pokrovskii V.V. Variants of human immunodeficiency virus type 1, detected in Russia among those infected by the sexual route. Vopr Virusol 2004; 49(1): 4-7.

9. Bobkov A.F., Kazennova Ye.V., Selimova L.M., Khanina T.A., Bobkova M.R., Ladnaya N.N., Kravchenko A.V., Pokrovskii V.V., Weber J.N. Nucleotide sequences GAG and ENV genes from human immunodeficiency virus type 1 isolates found in Russia: detection of new recombinant variants. Vopr Virusol 2000; 45(6): 17-20.

10. Kazennova E.V., Neshumaev D.A., Laga V.Yu., Lapovok I.A., Glushchenko N.V., Lebedev A.V., Bobkova M.R. Molekulyarno-epidemiologicheskaya kharakteristika epidemii VICh-infektsii v regionakh Sibiri i Dal'nego Vostoka Rossii. V kn.: Sbornik materialov VIII Vserossiyskoy nauchno-prakticheskoy konferentsii [Molecular epidemiological characteristics of HIV infection epidemics in Siberia and Far East regions. In: VIII AllRussian research and practice conference information package]. Moscow; 2014; p. 45-46.

11. Pokrovskiy V.V. Epidemiologiya $i$ profilaktika VIChinfektsii/SPID [Epidemiology and prevention of HIV infection/ AIDS]. Moscow: Meditsina; 1996; 248 p.

12. Bobkov A.F., Kazennova E.V., Selimova L.M., Ladnaia N.N., Bobkova M.R., Kravchenko A.V., Pokrovskii V.V. HIV-1 subtypes in Russia in 1987-1988. Zh Mikrobiol Epidemiol Immunobiol 1999; 1: 43-45.

13. Bobkov A., Kazennova E., Selimova L., Bobkova M., Khanina T., Ladnaya N., Kravchenko A., Pokrovsky V., Cheingsong-Popov R., Weber J. A sudden epidemic of HIV type 1 among injecting drug users in the former Soviet Union: identification of subtype $A$, subtype $B$, and novel gagA/envB recombinants. AIDS Res Hum Retroviruses 1998; 14(8): 669-676. 
14. Dement'yeva N.Ye., Sizova N.V., Lisitsyna Z.N., Belyakov N.A. Molecular and epidemiologic characteristic of HIV infection in Saint Petersburg. Meditsinskiy akademicheskiy zhurnal 2012; 12(2): 97-104.

15. Laisaar K.T., Avi R., DeHovitz J., Uuskbla A. Estonia at the threshold of the fourth decade of the AIDS era in Europe.
AIDS Res Hum Retroviruses 2011; 27(8): 841-851, http://dx.doi. org/10.1089/AID.2010.0223.

16. Delatorre E., Bello G. Spatiotemporal dynamics of the HIV-1 CRF06_cpx epidemic in Western Africa. AIDS 2013; 27(8): 1313-1320, http://dx.doi.org/10.1097/QAD. $0 \mathrm{~b} 013 \mathrm{e} 32835 \mathrm{f} 1 \mathrm{df} 4$. 